\title{
Revising our Curriculum/Empowering Students: Teachers' Preparation and Perceptions about Bilingual Writing
}

\author{
Maria Luisa Spicer-Escalante \\ Department of Languages, Philosophy, and Speech Communication, Utah State University, USA \\ Email: maria.spicer@usu.edu
}

\begin{abstract}
While emphasis on writing instruction has been a main concern in teaching Spanish to bilingual students in the U.S., it is an area in which very few theoretical advances have been made; in Mexico's case the situation is even more challenging. Therefore, based on classroom observations, and individual interviews with both teachers and students, and on the collection of class syllabi, this paper seeks to describe the current state of affairs regarding Spanish and English writing instruction for bilingual students in both countries. The main objectives are: 1) the analysis and comparison of the diverse teaching methodologies that high school teachers use to teach Spanish and English writing; 2) the analysis of the effects that the specific observed writing instruction has on students' perceptions about their own writing in both languages; and 3) the analysis of the perceptions that teachers have about their students' writing.
\end{abstract}

Index Terms — bilingual writing, teaching Spanish and English writing, teaching methodologies

\section{INTRODUCTION}

Research on writing is mainly carried out in the United States and other English speaking countries, and most of this research is related to English as a second language. In fact, several researchers have mentioned the need for more studies in other languages (Reichelt, 1999; Silva \& Matsuda, 2001; Spicer-Escalante, 2005; Spicer-Escalante, 2009). With respect to Hispanic bilingual students in the United States, even though the emphasis on writing instruction has been a main concern, it is, unfortunately, an area in which very few theoretical advances have been made (Martínez \& Spicer-Escalante, 2004; Valdés, 1995; Valdés, 1997; Valdés, 2006). Moreover, in the Spanish-speaking world, there is a noticeable lack of research into more advantageous strategies related to the teaching of writing. In the specific case of Mexico, we do not have access to either the current teaching methodologies that high school teachers use to teach Spanish writing or to the rhetorical and linguistic features of the Spanish writing of monolingual students. According to the Secretaría de Educación Pública (SEP) -the office in charge of Mexico's educational plans for elementary and secondary education at the national level- reading, writing, and mathematics are the most important areas of the Programa Nacional de Educación 2001-2006 (Secretaría de Educación Pública, 2001). Even though writing is considered an essential part of the national education program, this 270 page document does not specify which teaching methodologies are to be implemented to improve the writing of Mexican students.

\section{SPANISH AND ENGLISH BILINGUAL WRITING}

Research on Spanish and English bilingual writing indicates that their writing discourse displays certain specific characteristics at both the linguistic and the rhetorical level (Colombi, 2000; Colombi, 2003; Schleppegrell \& Colombi, 1997; Spicer-Escalante, 2002; Spicer-Escalante, 2007). The most important features at the linguistic level are, for example: the simplification of the verbal paradigm, the use of indicative instead of the subjunctive, and the preference of simple sentences instead over more complex subordinate sentences (Spicer-Escalante, 2007). At the rhetorical level, bilingual writing shows a greater use of detailed descriptions and narrations; an incorporation of analogies, testimonies, and examples to construct their essays; along with the tendency to support their thesis statements with the incorporation of personal experiences, or general knowledge, instead of using bibliographic information (Spicer-Escalante, 2005).

The analysis of the rhetorical and linguistic features of bilingual students writing in both Spanish and English in the United States suggests that their bilingual writing has unique characteristics that may be the result of a process of cultural --and rhetorical-transculturation ${ }^{1}$. That is, the writing of these bilingual students does not completely follow the rhetorical patterns and linguistic conventions of neither the English nor the Spanish languages. Regarding the specific case of their rhetorical strategies, for example, it is suggested that they find their own writing space between the

\footnotetext{
${ }^{1}$ This term refers to the reciprocal influences of modes of representation and cultural practices of various kinds. It describes how "subordinated or marginal groups select and invent from materials transmitted to them by a dominant or metropolitan culture" (Ashcroft, et al., 2000: 233).
} 
two languages and they nourish their writing expression by borrowing rhetorical aspects that correspond to both the Spanish and the English language (Spicer-Escalante, 2005).

Due to the aforementioned situations of both the writing instruction in the United States and in Mexico and the results yielded by the studies on bilingual writing, since the Fall of 2005 I have been conducting an ongoing study in two bilingual high schools; one in Albuquerque, New Mexico, and the other one in Guadalajara, Mexico. This study seeks to observe and to analyze the specific Spanish and English writing instruction that bilingual students receive at these two high schools. Although the research looks at several aspects of writing instruction, this essay focuses only on: 1) the analysis and comparison of the diverse teaching methodologies that high school teachers use to teach Spanish and English writing to bilingual students; 2) the analysis of the effects that the specific observed writing instruction has on students' perceptions about their own writing in both languages; and 3) the analysis of the perceptions that teachers have about their students' writing in both languages.

\section{Method AND SetTing OF THE StUdy}

The results of the present research have been drawn from classroom observations and individual interviews with both teachers and students conducted in the two aforementioned high schools. The class observations in Albuquerque were conducted in two English courses, taught by two different teachers, and in two Spanish courses for Native Speakers, taught by the same teacher. In Guadalajara observations were conducted in one English and in one Spanish course. A total of 20 students, both male and female, from each institution, were interviewed. The students who participated in this study were enrolled in the ninth or tenth grade. Both teachers and students were asked the same set of questions. The two English and one Spanish teacher, were interviewed in Albuquerque; the English teachers do not speak Spanish but the Spanish instructor is bilingual. In Guadalajara, the interviews were conducted with two English and with two Spanish teachers. The English instructors do not speak Spanish, even though one of them has lived in Mexico for eight years. The Spanish teachers understand English but do feel comfortable speaking it.

The high school in Albuquerque, the "Albuquerque Charter High School" (ACHS) is a Charter school located in the southwest area of Albuquerque. Diverse ethnic groups populate this area but Mexican and Mexican-Americans are the majority. According to ACHS statistics, its student population is $92 \%$ Hispanic; $100 \%$ of the students is at risk of not graduating; and $100 \%$ of them receive free breakfast and free lunch. Due to the history of the Hispanic population, in New Mexico the population goes back five centuries and there is a great variety of Spanish and English language proficiency levels among students at ACHS. Therefore, there are students who speak mainly Spanish, because they have recently arrived from a Hispanic country; while there are also students whose main language is English because their families have been in the area for several generations.

The bilingual school in Guadalajara, on the contrary, is quite different. Since the main objective of this research was to analyze the Spanish and English writing instruction to bilingual students, it was necessary to observe classes in the "Guadalajara Bilingual School" (GBS), a private institution. Traditionally, in México, Spanish/English bilingual students belong to the middle-upper level class and attend private institutions. The GBS is the most expensive private school in Guadalajara and it is located in one of the most affluent neighborhoods of this city. The GBS is a pre K-12 school and, according to its information, 94\% of the students are bilingual in Spanish and English. The remaining 4\% is represented by new arrivals, who are monolingual English speakers. All the students at the GBS not only finish high school but they also attend college and $100 \%$ of them finish their college studies. Moreover, a high percentage of them attend foreign universities, mainly in the United States. Guadalajara, the capital city of the State of Jalisco, is the second largest Mexican city with a population of over 5 million inhabitants; as a major economic hub for western Mexico, it is a city that constantly attracts new people from all over the country. Jalisco is also the state that supplies the largest number of immigrants to the United Sates (INEGI, 2000).

\section{TEACHER PREPARATION AND TEACHING EMPHASIS}

For the purpose of this essay, it is very important to underline the fact that teacher preparation on how to teach either Spanish or English writing is the key component not only to improve the students' writing skills but also, and more importantly, to empower both students and teachers with bilingual writing skills. Paraphrasing Kincheloe and McLaren, writing teachers should seek to empower their students by helping to raise their awareness of such systems so that they can challenge them (Kincheloe and McLaren, 1994; McLaren, 2007).

In other words, if teachers are aware of the complexity of the writing process and if they guide their students throughout this process, students will have a greater opportunity to become aware of not only the writing process but also the strengths and weaknesses of their own writing and on how to improve it. Only by being aware of the complexity of the writing process, will students be able to challenge it. The aforementioned claim is confirmed by the class observations and the individual interviews carried out for this study. However, before continuing with this discussion, it is important to describe the main characteristics of each school, as well as the similarities and differences in terms of the teaching practices in their Spanish and English courses.

Students in both schools take four 50-minute periods per week in their Spanish and their English classes. However, when comparing the pedagogical practices that teachers follow to teach Spanish and English writing, there are several 
distinctions that go beyond the expected differences given the two languages and the nature of both institutions (a public in the United States and a private school in Mexico).

The main observed differences are found in the teachers' academic preparation on the teaching of writing, the content that teachers cover in class, the type of writing exercises in which students are involved, and the way in which teachers respond to their students' writing. First of all, I must point out that teachers' academic background preparation in teaching in general varies between the two schools. At the Albuquerque Charter High School (ACHS), for example, one of the English teachers earned a Bachelors in English and she also holds an ESL (English as a Second Language) Endorsement; the other English teacher studied a Bachelors in Business, and years later, when she was already an English teacher, she got an ESL Endorsement; the Spanish teacher graduated with a Bachelors in Spanish. At the Guadalajara Bilingual School (GBS) the two Spanish teachers completed Bachelors and Masters degrees in Spanish Literature, in Mexico. The two English teachers graduated, one in Canada and the other one in the United States, with a Bachelors degree in English, and both of them hold Masters degrees in English Teaching.

In terms of teachers' preparation on how write, Spanish and English teachers from both institutions, three in ACHS and four in GBS, stated that they have learned how to write by writing. During their undergraduate coursework, all teachers took composition courses, in which they wrote different types of essays, but they did not receive specific instruction on how to write or on how to improve their writing. None of the seven teachers interviewed received instruction on how to teach writing during either their undergraduate, graduate, or while completing their ESL Endorsement coursework. Both of the English teachers at the GBS are creative writers and they are also involved in different study groups in which they have the opportunity to read, write, discuss, and practice different writing approaches and writing strategies. Even though they did not receive instruction on how to teach English writing during their undergraduate and graduate studies, they have continuously attended workshops on how to teach writing, and both of them are involved in the student magazine that is published by the GBS.

The situation regarding teacher preparation on how to teach writing with the rest of the teachers from both institutions is very different from the English teachers at GBS. The rest of the teachers attend several workshops on teaching, in general, but none of them has attended a workshop on the teaching of writing. They all stated that they had learned how to teach writing by observing other colleagues. However, what was observed during this study is that among the three teachers at the Albuquerque Charter High School (ACHS) and the two Spanish teachers at the Guadalajara Bilingual School (GBS) there is a misunderstanding on what it means to teach writing. That is, teachers conceive writing as the instruction, practice, and mastery of grammatical or lexical aspects of the language.

In the English classes at the ACHS, for example, students read and discuss literary passages in English. Both teachers provide students with a series of perfectly structured questions based on the readings. Teachers expose students to the reviews, explanations, discussions, and the practice of several grammatical or lexical aspects of the English language. In both classes students have to write essays that are reviewed by their teachers, and in which teachers indicate the different aspects that they have to correct for their final versions, such as misspellings, word order, or vocabulary. Sometimes, teachers also ask students to clarify or to extend some paragraphs. In one of the classes, students also have the opportunity to write free-writing pieces for the first five to ten minutes of class.

Historically, Spanish writing instruction to bilingual students in the United States has been focused on the teaching of the standard Spanish variety. Therefore, teaching reading and writing has involved instruction in spelling conventions, written accents, basic grammar explanations, and lexical practice (Spicer-Escalante, 2002). The Spanish teacher at the ACHS follows perfectly this traditional trend. Students in this class read short stories in Spanish and discuss them. Yet, most of the questions for these discussions were carried out in a random fashion; students had very few opportunities to actually write. All exercises were conducted in class because according to the teachers, "students at this school do not do homework" . Therefore, class time was spent reading short stories, explaining grammar and lexical conventions, and practicing vocabulary items and written accents.

The Spanish class at the GBS was a perfect grammar course. Students were exposed to very detailed and thorough grammar and lexical explanations of the Spanish language conventions, based on a series of readings. They also had to practice, in class and outside of class, the correct use of these different aspects; at the same time, they had to be able to recognize and explain these grammatical concepts. Students' writing was reviewed and graded by the teacher, based on the correct use of the Spanish language. The teacher pointed out the mistakes they had made in the essays, such as: word order, misspellings, written accents or word choice.

On the contrary, the teaching environment in the English classes at the GBS was very different. In this class, students had to read and discuss English literature. The teacher also provided them with grammatical or lexical explanations. However, students had the opportunity to be involved in the writing process. That is, they practiced on their own pieces the pre-writing, writing, and re-writing stages of rhetorical development. Students exchanged their essays with both their teacher and their classmates. During the review process, students had a series of structured questions to help them not only to better analyze their classmates' writing, but also to provide them with better, more structured feedback. Both teacher and student feedback focused mainly on the content and on the organizational aspects of the essays, not only on mechanical aspects. Students also had the opportunity to ask the teacher for clarification and to discuss, in class, some

${ }^{2}$ (Laura García, personal communication). 
of the most salient components of the compositions reviewed, before the re-write phase. After the pieces were graded, the teacher read some students compositions to the whole class to show them how their peers had incorporated particular rhetorical or linguistic features in their essays.

\section{TEACHERS’ AND STUdENTs’ Perceptions ABOUt BILINGUAL Writing}

The present study suggests that there is a very close correlation between teachers' background preparation, the teaching emphasis in the classroom, and the way that both students and teachers perceive writing. In classes where the emphasis is on the mechanical aspects of the language or on the grammar and lexical issues, students identify the need to master these aspects in order to be successful writers. Most students from both Spanish classes, at ACHS and GBS, as well as students from the English classes at ACHS consider, for example, that their writing is deficient because they do not know how to identify a verb or a noun in a sentence or because they do not know what an adverb is. In the case of the Spanish language this perception is even more critical because students think that knowing how to write in Spanish is to know how to correctly place written accents. Students have these opinions and make these assessments about their own writing because this is the instruction that they have received. Teachers emphasize the instruction and mastery of these mechanical aspects of the language in the classroom and when reviewing their written works. When Spanish and English teachers were asked to describe their students' writing, the Spanish teachers from both schools and the English teachers from ACHS noted that students do not know how to identify, or how to explain certain grammar features or lexical items (Spicer-Escalante, 2009).

However, students who know how the writing process works and who conceive writing beyond the mastery of these grammatical or lexical features, have a different, more complex understanding of the writing process. They realize that being a good writer is a goal that you can reach not only by reproducing correct grammar aspects or by being able to define them. For example, 100\% of the students from GBS recognize that their English writing is better after taking the English classes, while $80 \%$ of them express explicitly that their Spanish class has not helped them to improve their Spanish writing skills. As one of the students stated:

"We need more freedom to write in Spanish classes. For example, I do not want to be told to write a composition using all connectors that appear on a list. I want to use them correctly but in a free way. I spend my time trying to use all of them, instead of [...] thinking [...] how to express myself...I want to be able to express myself in Spanish as I do [...] in English" (Roberts, 2005)

In the English classes at ACHS and, especially in the Spanish classes at both High schools, teaching writing is not a priority; and it is not a priority because, as mentioned before, there is a misunderstanding on what it means to write. As Valdés (2002) says, our classrooms are full of good intentions. These teachers have wonderful intentions, but they have not received the appropriate instruction on how to write nor on teaching writing. When dealing with the teaching of writing, good intentions are not enough. It is urgent to better prepare our teachers to teach writing (Kaplan, 2008). With respect to the teaching of Spanish and English writing, we face multiple difficulties; the most important are the lack of a specific curriculum on the teaching of writing in both languages, and the lack of preparation of the Spanish and English teachers on how to teach writing.

\section{CONCLUSIONS}

Based upon the results of this study, we can state that we need to see writing in a different way, beyond the mechanical aspects of language. As Connor (1996) and Silva and Matsuda (2001) have mentioned, we need to understand the importance of the development of the rhetorical strategies that students use when they write. This does not mean that the mechanical features are not important, but that they should be seen as an integral part of their written discourse. These aspects are highly important tools that help students to improve their writing but should not be the main objective of instruction.

In dealing with the teaching of writing to bilingual students in the United States, we need to learn from the research conducted on the teaching of English writing to minority students (Ball, 1992; Ball \&Lardner, 1997; Delpit, 1988; Delpit, 2002; Elbow, 2000; Elsasser \& Irvine, 1985; Ladson-Billings, 1995; Ladson-Billings, 2002; Smitherman, 2000, among others). When dealing specifically with Hispanic students, we need to avoid what Ladson-Billings (1995) has termed 'permission to fail'. We need to establish and put into practice high standards for all our students, including Hispanics; they need to be prepared to be successful in life. They need to do homework! By allowing them not to do necessary class work, we are giving them permission to fail. We need to implement a "culturally relevant pedagogy" (Ladson-Billings, 1995) that focuses on students' academic achievement and a pedagogy that supports student's cultural competence.

We also need to design a specific curriculum for the teaching of Spanish and English writing, as well as guide our English and ESL teachers on the rhetorical and linguistic conventions of the Spanish language. Spanish teachers, on the other hand, need to find a correspondence between the English writing instruction that students receive and the application of these strategies to their Spanish writing.

In summary, as Colby and Stapleton (2006) have stated: "Teachers need to be writers themselves in order to be effective writing teachers" (354). In other words, we will be able to challenge the system only by being familiar with it, 
by being aware of how it works. As Gary Howard (2006) says "we can not teach what we do not know" or in the words of Ysabel Gracida, "if you do not write, you can not ask them to write. You cannot ask them to do something that you are not able to do" (2007). Only by preparing our Spanish and English teachers on how to teach writing, will we be able to provide students with the necessary tools needed to empower them to be better writers. Only by doing this, will they be able to express themselves in both languages and to believe in what they write.

\section{REFERENCES}

[1] Ashcroft, B., Griffiths, G., \& Tiffin H. (2000). Post-colonial studies: The key concepts. London and New York: Routledge.

[2] Ball, A. (1992). Cultural preference and the expository writing of African American adolescents. Written Communication, 9 (4), 501-32.

[3] Ball, A., \& Lardner, T. (1997). Dispositions toward language: Teacher constructs of knowledge and the Ann Arbor black English case. COLLEGE Composition and Communication, 48 (4), 469-485.

[4] Colby, S. \& Stapleton, J. (2006). Preservice teachers teach writing: Implications for teacher educators. Reading Research and Instruction, 45 (4), 353-76.

[5] Colombi, M. C. (2000). En vías del desarrollo del lenguaje académico en español en hablantes nativos del español en los Estados Unidos. In A. Roca (Ed.), Research on Spanish in the United States: Linguistic issues and challenges (pp. 296-309). Somerville: Cascadilla Press.

[6] Colombi, M. C. (2003). Un enfoque funcional para la enseñanza del ensayo expositivo. In A. Roca \& M. C. Colombi, (Eds.), Mi Lengua: Spanish as a Heritage Language in the United States (pp.78-95). Washington, D.C.: Georgetown University Press.

[7] Connor, U. (1996). Contrastive rhetoric. Cross-cultural aspects of second-language writing. Cambridge: Cambridge University Press.

[8] Delpit, L. (1988). The silenced dialogue: Power and pedagogy in educating other people's children. Harvard Educational Review, 58 (3), 280-98.

[9] Delpit, L. (2002). No kinda sense. In L. Delpit \& D. Kilgour, (Eds.), The skin that we speak (pp. 31-49). New York: The New York Press.

[10] Elbow, P. (2000). Everyone can write: Essays toward a hopeful theory of writing and teaching writing. New York: Oxford University Press.

[11] Elsasser N. \& Irvine, P. (1985). English and Creole: The dialectics of choice in a college writing program. Harvard Educational Review, 55 (4), 399-415.

[12] García, L. (2005). Personal interview. 19 September.

[13] Gracida, Y. (2007). Personal interview. 10 February.

[14] Howard, G. (2006). We can't teach what we don't know: White teachers, multiracial schools. New York: Teachers College.

[15] INEGI. (2000). XII censo general de población y vivienda, 2000. Base de datos de la muestra censal. México D. F.: INEGI.

[16] Kaplan, J. (2008). The national writing project: Creating a professional learning community that supports the teaching of writing. Theory Into Practice, 4, 336-344.

[17] Kincheloe, J. \& McLaren, P. (1994). Rethinking critical theory and qualitative research. In . N. Denzin \& Y. Lincoln, (Eds.), Handbook of qualitative research (pp.138-157). Thousand Oaks, CA: Sage.

[18] Ladson-Billings, G. (1995). Toward a theory of culturally relevant pedagogy. Education Research Journal, 35, $465-491$.

[19] Ladson-Billings, G. (2002). I ain't writin'nuttin': Permission to fail and demands to succeed in urban classrooms. In L. Delpit \& D. Kilgour, (Eds.), The skin that we speak (pp. 107-120). New York: The New York Press.

[20] Martínez, G. \& M. Spicer-Escalante. (2004). Freewriting vs. Graded Writing: Rhetorical Features of Spanish Heritage Learners. Paper presented at the 38 th ACTFL Convention. Chicago, Illinois.

[21] McLaren, P. (2007). The future of the past: Reflections on the present state of empire and pedagogy. In P. McLaren \& J. Kincheloe, (Eds.), Critical pedagogy. Where are we now? (pp. 289-314). New York: Peter Lang.

[22] Smitherman, G. (2000). Talking that talk: Language, culture, and education in African-American. New York: Routledge.

[23] Reichelt, M. (1999). Toward a more comprehensive view of L2 writing: Foreign language writing in the U. S. Journal of Second Language Writing, 8, 181-204.

[24] Roberts, D. (2005). Personal interview. 29 November.

[25] Secretaría de Educación Pública. (2001). Programa Nacional de Educación 2001-2006. México, D. F.: Secretaría de Educación Pública.

[26] Schleppegrell, M. \& M. C. Colombi. (1997). Text organization by bilingual writers. Written Communication, 14, $481-503$.

[27] Silva, T. \& Matsuda, P. (2001). Preface. In T. Silva \& P. Matsuda, (Eds.), On second language writing (pp. xi-xvi). Mahwah: Lawrence Erlbaum Associates.

[28] Spicer-Escalante, M. (2002). Spanish heritage speakers' Spanish and English writings: Contrastive rhetorical and linguistic analyses, Ph.D. Unpublished Dissertation, University of Illinois at Urbana-Champaign.

[29] Spicer-Escalante, M. (2005). Writing in two languages/living in two worlds: Rhetorical analysis of Mexican-American written discourse. In M. Farr (Ed.), Latino language and literacy in ethnolinguistic Chicago (pp. 217-244). New Jersey/London: Lawrence Earlbaum Associates.

[30] Spicer-Escalante, M. (2006). The use of verbal forms in the Spanish and English writing discourse of Spanish heritage speakers in the United States: A contrastive linguistic analysis. Río Bravo: A Journal of Borderlands, 2 (1), 13-24.

[31] Spicer-Escalante, M. (2007). Análisis lingüístico de la escritura bilingüe (español inglés) de los hablantes de herencia en los Estados Unidos. Estudios de Lingüística Aplicada, 45, 63-80.

[32] Spicer-Escalante, M. (2009). La enseñanza de la escritura de textos académicos para los estudiantes bilingües: prácticas pedagógicas de dos preparatorias en México y en los Estados Unidos. Textos. Didáctica de la Lengua y la Literatura, 50, 68-77.

[33] Valdés, G. (1995). The teaching of minority languages as' foreign' languages: Pedagogical and theoretical challenges. Modern Language Journal, 79, 299-328. 
[34] Valdés, G. (1997). The teaching of Spanish to bilingual Spanish speaking students: Outstanding issues and unanswered questions. In M. C. Colombi \& F. Alarcón, (Eds.), La enseñanza del español a hispanohablantes. Praxis y teoría (pp.8-44). Boston: Houghton Mifflin.

[35] Valdés, G. (2002). Learning and not learning English. Latino students in American schools. New York: Teachers College.

Maria Luisa Spicer-Escalante is an Associate Professor of Spanish and Linguistics (Ph.D. University of Illinois, UrbanaChampaign, 2002). She teaches courses in Spanish and Linguistics both at the undergraduate and graduate level. She is the CoDirector of the Master of Second Language Teaching program at Utah State University. Her research focuses on the pedagogical aspects of Second Language Acquisition, Bilingual Education, and Spanish Heritage Speakers in the United States. 